\title{
Varieties and mulching influence on weed growth in wheat under Indo- Gangetic plain of India
}

\author{
Diwakar Mani, M.K. Singh and S.K. Prasad \\ Pradesh), INDIA \\ ${ }^{*}$ Corresponding author. E-mail: manoj.agro@bhu.ac.in \\ Received: September 18, 2015; Revised received: February 18, 2016; Accepted: April 8, 2016
}

Department of Agronomy, Institute of Agricultural Sciences, Banaras Hindu University, Varanasi- 221005 (Uttar

\begin{abstract}
Weeds are one of the primary factors responsible for reducing wheat yield. Despite, herbicides' being one of the important components of weed management programme in India, but it was not adopted by resource poor farmers. Keeping these facts in view, a field experiment was carried out at Agricultural research farm, Institute of Agricultural sciences, Banaras Hindu University during the rabi (winter) season of the year 2012-13 to scrutinize the influence of 'mulching' and 'varieties' on weed control potential as well as growth and yield of wheat. The treatments comprised of five wheat varieties (C-306, K-8027, K-0307, DBW-39 and HD-2888) and four mulching treatments (No -mulch, paddy straw 6t/ha, maize straw 6t/ha, and saw dust $6 \mathrm{t} / \mathrm{ha}$ ). Surface application of paddy straw mulch $6 \mathrm{t} / \mathrm{ha}$ considerably reduced the density and biomass of broad leafed weeds and grasses and showed higher weed control efficiency over other treatments like maize straw 6t/ha, saw dust 6t/ha and no-mulch. Varieties DBW-39 and K-0307 was highly effective in smothering of the weeds and produced higher dry matter accumulation, leaf area index, number of grain/earhead, biological yield and harvest index of wheat.
\end{abstract}

Keywords: Cultivars, Maize straw, Paddy straw, Saw dust, Weed control efficiency

\section{INTRODUCTION}

Wheat is one of the most important agricultural crops in India. It accounts for 12 per cent of the total cultivable land area, contributes 3 per cent in the country's gross domestic product (GDP) (Singh et al., 2013); and moreover,it is one of the important source of energy and protein (Sharma et al., 2008). Recent report showed that India's wheat production has reached to $96 \mathrm{M}$ tons from an area of 29 Mha with an average productivity $2.7 \mathrm{t} /$ ha (Swaminathan, 2013). But, to fulfill the demand of burgeoning population, wheat production needs to be increase by $110-120 \mathrm{M}$ tons by 2051 A. D.; by that time it is expected the area under wheat production decreased by 5-6 M ha. Thus average wheat productivity needs to increase up to $5 \mathrm{t} / \mathrm{ha}$ to feed the population (Sharma et al., 2013). Weeds caused serious threat to wheat production (Kumar et al., 2008); accounts for 20-40 per cent losses in wheat yield (Sharma, 2009). Therefore, for realizing full genetic yield potential of the crop and sustaining food grain production to feed the ever-increasing population, weed management is essential (Singh and Chhokar, 2012).

Because of higher economic cost of labour for manual weeding, herbicides are widely preferred by farmers (Singh et al. 2014), but its continuous usage for longer duration leads to shift in weed flora, increase in residual toxicity to the succeeding crops (Chhokar et al.,
2006), development of herbicide resistance in weeds (Singh, 2007) and also increase the cost of crop production (Vincent and Quirke, 2002). Therefore, these situations force the researchers to search some economically viable, ecological sustainable and technologically feasible options of weed management in wheat.

Use of mulch and competitive varieties has potential to sustainably manage the weeds at low cost. Plenty of organic mulch materials viz. paddy straw, maize straw and saw dust are easy accessible to the farmers of eastern Uttar Pradesh in their villages. In fact researches showed that application of paddy straw mulch $6 \mathrm{t} / \mathrm{ha}$ (Brar and Walia, 2010) reduced biomass and density of weeds in wheat. In addition, organic mulches improve the physical, chemical and biological properties of soil (Kasirajan and Ngouajio, 2012) and increase the crop yield (Brar and Walia, 2010).

Futhermore, selection of appropriate crop varieties may have a profound effect on crop-weed competition. Varietal characteristics, like, taller plant height, size of flag leaf, higher leaf size and leaf area index, high specific leaf area during vegetative growth, and allelopathic ability (Joshi et al., 2007, Bertholdsson and Brantestam, 2009) makes one variety more competitive with weeds than another.

Literature reveals that there are meager studies conducted in wheat to evaluate the effect of varieties and mulch materials on weed and crop growth. Keeping 
above facts in view, present investigation was carried out with the objective to evaluate the weed suppression ability and crop response of different mulches and varieties of wheat.

\section{MATERIALS AND METHODS}

Site and soil information: The experiment was carried out during winter season (Rabi) season of 201213 at Agricultural research farm, Institute of Agricultural sciences, Banaras Hindu University, Varanasi (U.P), situated in Indo-Gangetic plain $\left(25^{\circ} 18^{\prime} \mathrm{N}\right.$, $83^{0} 03^{\prime} \mathrm{E}, 128.93 \mathrm{~m}$ amsl). The soil of the experimental site was sandy clay loam, organic carbon $0.52 \%, \mathrm{pH}$ 8.53, available NPK 175.56, 22.1, $227.5 \mathrm{~kg} / \mathrm{ha}$, respectively. The weather in this area is characterized by hot, dry summers and cold winters. During crop growth period, maximum and minimum temperature ranges from $39.2-17.1^{\circ} \mathrm{C}$ and $5.8-21.1^{\circ} \mathrm{C}$, respectively. Maximum $\left(39.2^{\circ} \mathrm{C}\right)$ and minimum $\left(5.8^{\circ} \mathrm{C}\right)$ temperature recorded in month of April and January, respectively. Total rainfall received during the crop growing period was $22.1 \mathrm{~mm}$, and average evaporation during the period of experimentation varied from 0.9 to $7.2 \mathrm{~mm}$ per day.

Trial establishment: The experiment was laid out in two factor factorial completely randomized block design, having plot size $4 \times 3 \mathrm{~m}$ with three replications. First factor comprised of five wheat varieties (C-306, K-8027, K-0307, DBW-39 and HD-2888) whereas, second factor consist of four mulching treatments [Nomulch (NM), paddy straw 6t/ha (PSM), maize straw 6t/ ha (MSM), and saw dust 6t/ha (SDM)]. Quantity of mulch materials was quantified on dry weight basis. Recommended seed rate $(100 \mathrm{~kg} / \mathrm{ha})$ of wheat was sown at $5 \mathrm{~cm}$ depth in open furrows made with a manual single row drill at a row spacing of $22.5 \mathrm{~cm}$ and immediately covered with soil on December 06, 2012. Mulch material was applied immediately after sowing of wheat. Recommended rates of fertilizers $120 \mathrm{~kg} \mathrm{~N}$, $60 \mathrm{~kg} \mathrm{P}_{2} \mathrm{O}_{5}$ and $40 \mathrm{~kg} \mathrm{~K}_{2} \mathrm{O}$ /ha were applied through urea, single super phosphate, and muriate of potash, respectively. Whole of phosphorus and potassium and half rate of nitrogen were applied at the time of sowing. The remaining half -rate of nitrogen was applied as top dressing at 22 DAS (CRI stage) and 46 DAS (booting stage). Crop was harvested on 29 April, 2013.

Biometerical observation: Data on weed density and biomass were recorded at 60 DAS. Weed samples were randomly collected from 2-places in each plot with the help of quadrate (size $31.62 \times 31.62 \mathrm{~cm}$ ). To estimate the density of weeds, uprooted weed samples were classified under broadleaf, grasses and sedges thereafter counted and values were presented in number $/ \mathrm{m}^{2}$. Uprooted weed samples were placed in a paper bag, and dried for $48 \mathrm{~h}$ in an oven at $60^{\circ} \mathrm{C}$, then weighed to determine weed biomass and values are presented in $\mathrm{g} / \mathrm{m}^{2}$. The weed control efficiency (WCE) was calculated on the basis of reduction in weed biomass in treated plot as compared to control (no-mulch) plot and express in percentage (Anwar et al., 2013). Similar formula is also used to estimate the WCE on density basis, where density of weeds was taken in account instead of biomass.

Dry matter accumulation by wheat was recorded at 30 and 60 DAS, whereas, leaf area index (LAI) was recorded at 60 DAS. Wheat dry matter was taken from above ground plants samples, from random selected area of 1 meter in running length for wheat crop. The samples were sun dried and then dried in oven at $60^{\circ} \mathrm{C}$ till a constants weight was obtained, then values were converted to $\mathrm{g} / \mathrm{m}^{2}$. LAI was measured from 5-spots in intra-row spaces of wheat crop using AccuPar PAR/ LAI ceptometer model: LP-80, which calculates LAI based on the above and below-canopy PAR measurements (Singh et al., 2015). Thereafter, values from each plot are averaged to obtain a single value. Yield attributing parameters like, spike length (earhead) and number of grain/earhead was obtained from five randomly selected ears from each plot and their length and number of grain per earhead were recorded. Biological yield ( $\mathrm{kg} / \mathrm{ha})(\mathrm{BY} d)$ was calculated after harvesting above ground plant parts from net plot area of each plot and values were expressed into $\mathrm{kg} / \mathrm{ha}$. However, harvest index (HI) was calculated as per the formula suggested by (Unkovich et al., 2010).

Statistical analysis: Data was collected on wheat and weeds were tabulated and statistically analyzed as per the standard analysis of variance to draw valid conclusions (Gomez and Gomez, 1984). The treatment differences were tested by ' $F$ ' test of significance on the basis of null hypothesis. Critical differences were work out at 5 per cent level of probability where ' $F$ ' test was significant. Heterogeneous weed (density and biomass) data were square-root transformed i.e. $\sqrt{ }(\mathrm{X}+0.5)$, prior to analysis to produce a near normal distribution, however, non-transformed data are also presented for clarity.

\section{RESULTS AND DISCUSSION}

Effect on weed: The experimental field during the cropping season was infested with 7-winter (rabi) season weeds. Predominant weed species among the grasses are Phalaris minor Retz. and Cynodon dactylon (L) Pers whereas, Chenopodium album L, Melitlotus sp. Parthenium hysterophorus L. and Rumex dentatus L. among broadleaf weeds (BLWs). Moreover, among sedges only one species Cyperus rotundus L. was observed.

Varieties: Wheat varieties C-306, K-8027 and HD2888 showed significantly highest density and biomass of BLWs and grassy weed; however, except HD-2888 showed relatively lower biomass of grassy weeds as compared to C-306, K-8027 (Table 1). Whereas, lowest density and biomass of BLWs and grassy weeds were observed under DBW-39 and was statistically 
Table 1. Effect of varieties and mulching on density and biomass of broadleaf, grasses, sedges and WCE in wheat.

\begin{tabular}{|c|c|c|c|c|c|c|c|c|}
\hline \multirow[b]{2}{*}{ Treatment } & \multicolumn{4}{|c|}{ Density (number $\left./ \mathrm{m}^{2}\right)^{\mathrm{a}}$} & \multicolumn{3}{|c|}{$\operatorname{Biomass}\left(\mathrm{g} / \mathrm{m}^{2}\right)^{\mathrm{a}}$} & \multirow[b]{2}{*}{$\begin{array}{l}\text { WCE (\%) } \\
\text { (biomass } \\
\text { basis) }\end{array}$} \\
\hline & BLWs & Grasses & Sedges & $\begin{array}{l}\text { WCE }(\%) \\
\text { (density basis ) }\end{array}$ & BLWs & Grasses & Sedges & \\
\hline \multicolumn{9}{|l|}{ Varieties } \\
\hline C-306 & $\begin{array}{l}9.26 \\
(85.42)\end{array}$ & $\begin{array}{l}4.38 \\
(18.75)\end{array}$ & $\begin{array}{l}1.95 \\
(3.33)\end{array}$ & 3.48 & $\begin{array}{l}4.50 \\
(19.82)\end{array}$ & $\begin{array}{l}3.16 \\
(9.53)\end{array}$ & $\begin{array}{l}0.89 \\
(0.30)\end{array}$ & 29.81 \\
\hline K-8027 & $\begin{array}{l}9.57 \\
(91.25)\end{array}$ & $\begin{array}{l}4.24 \\
(17.50)\end{array}$ & $\begin{array}{l}2.43 \\
(5.42)\end{array}$ & 14.07 & $\begin{array}{l}4.40 \\
(18.91)\end{array}$ & $\begin{array}{l}2.44 \\
(5.50)\end{array}$ & $\begin{array}{l}0.93 \\
(0.38)\end{array}$ & 37.55 \\
\hline K-0307 & $\begin{array}{l}6.98 \\
(48.33)\end{array}$ & $\begin{array}{l}3.54 \\
(12.08)\end{array}$ & $\begin{array}{l}2.34 \\
(5.00)\end{array}$ & 32.43 & $\begin{array}{l}3.20 \\
(9.80)\end{array}$ & $\begin{array}{l}2.68 \\
(6.69)\end{array}$ & $\begin{array}{l}1.00 \\
(0.51)\end{array}$ & 34.45 \\
\hline DBW-39 & $\begin{array}{l}7.67 \\
(58.33)\end{array}$ & $\begin{array}{l}3.30 \\
(10.42)\end{array}$ & $\begin{array}{l}2.90 \\
(7.92)\end{array}$ & 31.92 & $\begin{array}{l}3.71 \\
(13.30)\end{array}$ & $\begin{array}{l}2.03 \\
(3.66)\end{array}$ & $\begin{array}{l}0.92 \\
(0.36)\end{array}$ & 42.70 \\
\hline HD-2888 & $\begin{array}{l}8.87 \\
(78.33)\end{array}$ & $\begin{array}{l}3.48 \\
(11.67)\end{array}$ & $\begin{array}{l}2.34 \\
(5.00)\end{array}$ & 23.23 & $\begin{array}{l}4.22 \\
(17.33)\end{array}$ & $\begin{array}{l}2.23 \\
(4.48)\end{array}$ & $\begin{array}{l}0.97 \\
(0.46)\end{array}$ & 28.70 \\
\hline $\operatorname{SEm} \pm$ & 0.62 & 0.21 & 0.09 & - & 0.26 & 0.16 & 0.05 & - \\
\hline $\begin{array}{l}\mathrm{CD} \\
(\mathrm{P}=0.05) \\
\text { Mulching }\end{array}$ & 1.78 & 0.59 & 0.26 & - & 0.75 & 0.46 & NS & - \\
\hline No- Mulch & $\begin{array}{l}9.61 \\
(92.00)\end{array}$ & $\begin{array}{l}4.02 \\
(15.67)\end{array}$ & $\begin{array}{l}3.24 \\
(10.00)\end{array}$ & 0.00 & $\begin{array}{l}5.00 \\
(24.57)\end{array}$ & $\begin{array}{l}3.29 \\
(10.33)\end{array}$ & $\begin{array}{l}1.14 \\
(0.80)\end{array}$ & 0.00 \\
\hline $\begin{array}{l}\text { Paddy } \\
\text { straw 6t/ } \\
\text { ha }\end{array}$ & $\begin{array}{l}6.62 \\
(43.33)\end{array}$ & $\begin{array}{l}3.93 \\
(15.00)\end{array}$ & $\begin{array}{l}1.08 \\
(0.67)\end{array}$ & 54.24 & $\begin{array}{l}2.87 \\
(7.76)\end{array}$ & $\begin{array}{l}1.81 \\
(2.80)\end{array}$ & $\begin{array}{l}0.77 \\
(0.10)\end{array}$ & 69.47 \\
\hline $\begin{array}{l}\text { Maize } \\
\text { straw 6t/ } \\
\text { ha }\end{array}$ & $\begin{array}{l}7.19 \\
(51.33)\end{array}$ & $\begin{array}{l}3.34 \\
(10.67)\end{array}$ & $\begin{array}{l}2.12 \\
(4.00)\end{array}$ & 38.05 & $\begin{array}{l}3.32 \\
(10.55)\end{array}$ & $\begin{array}{l}2.31 \\
(4.86)\end{array}$ & $\begin{array}{l}0.88 \\
(0.28)\end{array}$ & 53.80 \\
\hline $\begin{array}{l}\text { Saw dust } \\
6 \mathrm{t} / \mathrm{ha}\end{array}$ & $\begin{array}{l}10.15 \\
(102.67)\end{array}$ & $\begin{array}{l}3.93 \\
(15.00)\end{array}$ & $\begin{array}{l}2.67 \\
(6.67)\end{array}$ & -8.18 & $\begin{array}{l}4.57 \\
(20.45)\end{array}$ & $\begin{array}{l}2.52 \\
(5.89)\end{array}$ & $\begin{array}{l}0.96 \\
(0.43)\end{array}$ & 15.30 \\
\hline $\operatorname{SEm} \pm$ & 0.56 & 0.18 & 0.08 & - & 0.24 & 0.14 & 0.04 & - \\
\hline $\begin{array}{l}C D \\
(P=0.05)\end{array}$ & 1.60 & 0.53 & 0.23 & - & 0.67 & 0.41 & 0.13 & - \\
\hline $\mathrm{V} \times \mathrm{M}$ & NS & NS & NS & - & NS & NS & NS & - \\
\hline
\end{tabular}

Data is subjected to square root transformation $(\sqrt{ } \mathrm{x}+0.5)$ and non transformed data is mentioned in the parenthesis

${ }^{a}$ Observation recorded at 60 DAS

Table 2. Effect of varieties and mulching on plant growth parameter, yield attributes and yield.

\begin{tabular}{|c|c|c|c|c|c|c|c|}
\hline \multirow{3}{*}{ Treatments } & \multicolumn{3}{|c|}{ Growth parameter } & \multicolumn{2}{|c|}{ Yield attributes } & \multicolumn{2}{|l|}{ Yield } \\
\hline & \multicolumn{2}{|c|}{ Plant dry matter $\left(\mathrm{g} / \mathrm{m}^{2}\right)$} & \multirow{2}{*}{$\begin{array}{l}\begin{array}{l}\text { Leaf area index } \\
\text { (LAI) }\end{array} \\
60 \text { DAS }\end{array}$} & \multirow{2}{*}{$\begin{array}{l}\text { Spike } \\
\text { length } \\
\text { (cm) }\end{array}$} & \multirow{2}{*}{$\begin{array}{l}\text { Number of } \\
\text { grain/ } \\
\text { earhead }\end{array}$} & \multirow{2}{*}{$\begin{array}{l}\text { Biological } \\
\text { yield (kg/ } \\
\text { ha) }\end{array}$} & \multirow{2}{*}{$\begin{array}{l}\text { Har- } \\
\text { vest } \\
\text { index } \\
(\%)\end{array}$} \\
\hline & 30 DAS & 60 DAS & & & & & \\
\hline \multicolumn{8}{|l|}{ Varieties } \\
\hline C-306 & 14.22 & 254.33 & 2.51 & 15.35 & 39.75 & 72.05 & 37.29 \\
\hline K-8027 & 15.11 & 305.89 & 2.43 & 15.75 & 41.50 & 78.35 & 38.66 \\
\hline K-0307 & 23.03 & 294.75 & 3.06 & 14.62 & 43.50 & 83.58 & 36.74 \\
\hline DBW-39 & 18.14 & 239.87 & 2.77 & 13.05 & 45.50 & 106.68 & 37.21 \\
\hline HD-2888 & 19.19 & 302.97 & 2.89 & 14.52 & 38.50 & 74.40 & 36.90 \\
\hline SEm \pm & 1.94 & 31.12 & 0.18 & 0.27 & 0.66 & 1.32 & 0.57 \\
\hline $\mathrm{CD}(\mathrm{P}=0.05)$ & 5.54 & NS & 0.52 & 0.76 & 1.88 & 3.78 & 1.64 \\
\hline \multicolumn{8}{|l|}{ Mulching } \\
\hline No- Mulch & 16.35 & 242.74 & 2.46 & 14.61 & 35.40 & 71.80 & 34.57 \\
\hline Paddy straw & & & & 14.55 & 47.20 & 87.90 & 41.54 \\
\hline $6 \mathrm{t} / \mathrm{ha}$ & 19.27 & 304.44 & 2.89 & & & & \\
\hline Maize straw & & & & 14.87 & 44.00 & 88.88 & 37.71 \\
\hline $6 \mathrm{t} / \mathrm{ha}$ & 18.03 & 259.74 & 2.67 & & & & \\
\hline Saw dust & & & & 14.60 & 40.40 & 83.46 & 35.62 \\
\hline $6 \mathrm{t} / \mathrm{ha}$ & 18.10 & 311.32 & 2.90 & & & & \\
\hline $\mathrm{SEm} \pm$ & 1.73 & 27.83 & 0.16 & 0.24 & 0.59 & 1.18 & 0.51 \\
\hline $\mathrm{CD}(\mathrm{P}=0.05)$ & NS & NS & NS & NS & 1.68 & 3.38 & 1.47 \\
\hline $\mathrm{V} \times \mathrm{M}$ & NS & NS & NS & NS & NS & $\mathrm{S}$ & NS \\
\hline
\end{tabular}


Table 3. Integrated effects of varieties and mulching on biological yield.

\begin{tabular}{lllll}
\hline & \multicolumn{4}{c}{ Biological yield(kg/ha) } \\
\cline { 2 - 5 } $\begin{array}{l}\text { Varie- } \\
\text { ties }\end{array}$ & $\begin{array}{l}\text { Mo- } \\
\text { Mulch }\end{array}$ & $\begin{array}{l}\text { Paddy } \\
\text { straw 6t/ } \\
\text { ha }\end{array}$ & $\begin{array}{l}\text { Maize } \\
\text { straw } \\
\text { ha }\end{array}$ & $\begin{array}{l}\text { Saw } \\
\text { dust 6t/ } \\
\text { ha }\end{array}$ \\
\hline C-306 & 66.00 & 76.80 & 75.40 & 70.00 \\
K-8027 & 58.00 & 84.40 & 90.00 & 81.00 \\
K-0307 & 76.00 & 90.50 & 86.40 & 81.40 \\
DBW- & 78.00 & 112.80 & 117.00 & 118.90 \\
39 & & & 75.60 & 66.00 \\
HD- & 81.00 & 75.00 & 7.55 & \\
2888 & & & & \\
CD (P=0.05) & & 7.55 & \\
\hline
\end{tabular}

similar to K-0307, except for biomass of grassy weeds. Biomass accumulation by sedges under different wheat varieties differed non-significantly; however, significantly highest and lowest density of sedges were recorded under DBW-39 and C-306, respectively, although rest of the varieties showed at par density of sedges among themselves. Highest WCE (on density basis) observed under variety K-0307 followed by DBW-39 and HD-2888, however, highest WCE (on biomass basis) recorded under DBW-39 followed by K -0307. Variety C-306 showed lowest WCE.

Mulch: Application of SDM and NM treatments produced highest density and biomass of BLWs and grasses, except biomass produced by grasses under SDM was statistically lower than NM $(\mathrm{P}<0.05)$ (Table 1). Application of PSM and MSM produced at par lower density and biomass of BLWs and grasses. In fact, biomass produced by grassy weeds was comparatively lower under MSM over PSM. Significantly highest density and biomass of sedges was observed under NM followed by SDM, whereas, lowest sedges growth was observed under PSM. Highest WCE on both density and biomass was observed under PSM followed by MSM.

Effect on crop Varieties: Plant dry matter (DM) accumulation did not differed significantly with wheat varieties at 60 DAS (Table 2). However, significantly higher plant DM accumulation at 30 DAS and LAI at 60 DAS was produced by K-0307, and it was statistically at par to DBW-39 and HD-2888, furthermore, variety C-306 produced lowest DM accumulation and LAI and was statistically similar to the varieties $\mathrm{K}$ 8027, DBW-39 and HD-2888.

Significantly highest spike length was produced by the variety C-306 and K-8027, whereas, lowest spike length was produced by DBW-39. Contrary to spike length, significantly highest number of grain/earhead produced by the variety DBW-39 followed by K-0307, C-306 and K-8027; later two varieties showed at par results. Wheat variety DBW-39 produced significantly highest BYd followed by K-0307, whereas, lowest $\mathrm{BY} d$ was recorded under C-306 followed by HD-2888. Moreover, wheat variety K-8027 produced highest HI was observed under varieties K-8027and was statistically similar to DBW-39 and C-306; however, lowest HI was observed under HD-2888 and it was statistically similar to DBW-39 and C-306.

Mulch: Application of different mulch materials did not showed marked influence on plant dry weight, LAI and spike length of wheat (Table 2). However, application of the PSM produced higher number of grain/ earhead followed by MSM, SDM and NM treatment, respectively. Application of both PSM and MSM produced statistically similar highest BYd. However, lowest BY $d$ was obtained under NM. Further, observation on HI clearly revealed significantly highest values obtained under PSM followed by MSM, whereas, significantly at par lowest HI observed under SDM and NM treatments.

Integrated effects of varieties and mulching on biological yield: Interaction of variety $\mathrm{x}$ mulching showed that different mulches x DBW-39 produced statistically at par BYd, however, at the same time, different mulch X DBW-39 produced higher BY $d$ over NM x DBW-39 (Table 3). Almost similar BYd was produced under the variety K-8027 and K-307 in combination with different mulches and was significantly lower over DBW-39 x different mulches. SDM in combination with the variety C-306 and HD-2888 recorded lowest BYd and both these combinations showed statistically at par results.

Experimental findings indicated that during initial stage of crop growth due to higher early plant vigour the variety DBW-39 followed by K-0307 showed higher dry matter accumulation and LAI as compared to the rest of the varieties. Even these varieties i.e. DBW-39 and K-0307 maintain higher LAI throughout crop growth stages (data not shown). Higher plant growth under DBW-39 and K-0307 negatively affect weed growth, particularly, BLWs and grasses which contribute to the maximum density and biomass accumulation by weeds. Similar to our findings, Lemerle et al. (1996) tested 250 genotypes of wheat for competitiveness against Lolium rigidum, they concluded that strongly competitive genotypes had high early biomass accumulation with extensive leaf display. Andrew et al. (2015) also opined that early plant vigour and canopy architecture are the important traits in cereals imparting competitive ability against weed.

It was established fact that heavy weed infestation, particularly during the critical period of crop-weed competition (CP of CWC) i.e. 30-50 DAS, negatively influences growth and yield of wheat, and this fact was well visualized in NM treatment, where weed infestation during $\mathrm{CP}$ of $\mathrm{CWC}$ drastic reduced plant dry weight, LAI and biological yield.

Khan (2002) also observed that weed competition beyond 42 days, i.e. up to 56 days or longer, significant reduced wheat yield. Similarly, Chaudhary et al., (2008) recorded highest grain yield when weeds were removed after 30 days followed by 40 days and 50 
days after sowing .

PSM and MSM produced higher BY $d$ as compared to SDM and NM treatments, the reasons for increased BYd could be attributed to two reasons: firstly, application of straw mulches buffers the soil temperature (Acharya et al., 2005) and helps in conservation of moisture (Araya and Stroosnijde, 2010), this will help in increased germination of wheat seedlings as compared to NM treatment, secondly, there was reduced germination of weeds under PSM might be due to rice residues contains eight phenolic acids, including cinnamic acid, salicylic acid, vanillic acid, phydroxybenzoic acid, 2,5-dihydroxybenzoic acid, ferulic acid, o-coumaric acid and p-coumaric acid (ElShahawy et al., 2006). These phenolic acids considered as the key factor of rice allelopathy against suppressing a wide range of mono and dicotyledonous weeds in different crops. Chung et al. (2001) also reported allelopathic effect of rice residue on barnyard grass. Both these conditions provides favorable environment for acquisition of natural resources by crop plants thus resulted in increased number of grain/ earhead, BYd and HI of wheat. Singh and Saini (2008) also observed weed suppression and positive effect on plant growth with PSM application. Further, application of MSM produced almost similar results to that of PSM in most of the parameters related to weed suppression and growth and yield attributes of wheat. In fact, researches reveal that positively influence of MSM on weed suppression might be due to release of some allelochemicals, like benzoxazolinone, 5-chloro6-methoxy-2-benzoxazolinone (Cl-MBOA), and 6methoxy-2-benzoxazolinone (MBOA) (Kato-Noguchi (2000) during degradation of straw. These allelochemicals have potential to inhibit germination of crops (rice and pea seedling) and weeds (Maranthus caudatus, Lepidium sativum, Lactuca sativa, Digitaria sanguinalis, Phleum pretense, Lolium multiflorum) (KatoNoguchi, 2000), but in the later stages crop can easily overcome these allelopathic responses. Allelopathic inhibition of weeds germinations might be one of the key reasons for reduced weed growth in our experiment. Borghi et al. (2008) also reported reduced weed growth with application of maize straw. Moreover, reasons for lower grain/per earhead yield under maize straw mulch may be due to poor partitioning of photosynthate from vegetative to reproductive organs results in reduced number of grain/earhead.

\section{Conclusion}

On the basis of this investigation it was concluded that varietal selection and application of mulch has ample potential for weed management in wheat. Furthermore, under the late sown condition of eastern Uttar Pradesh, wheat variety DBW-39 was found highly effective for suppression of weed growth, particularly during critical crop-weed competition period and recorded higher number of grain/earhead, biological yield and harvest index followed by K-0307. Application of paddy straw $6 \mathrm{t} / \mathrm{ha}$ mulch and maize straw $6 \mathrm{t} / \mathrm{ha}$ mulch was found better which not only increased biological yield and HI of wheat but also reduced the growth of different weeds. This research further implicated that adoption of above-said varieties and mulch material provide low cost, technological feasible option, especially for small and marginal farmers of Indo-Gangetic plain, to manage the weeds and boost production and productivity of wheat.

\section{REFERENCES}

Acharya, C.L., Hati, K.M. and Bandyopadhyay, K.K. (2005). Mulches. Encyclopedia of Soils in the Environment. Elsevier, New York, pp 521-532.

Andrew, I.K.S., Storkey, J. and Sparkes, D.L. (2015). A review of the potential for competitive cereal cultivars as a tool in integrated weed management. Weed Res., 55 (3): 239-248.

Anwar, M.P., Juraimi, A.S., Mohamed, M.T.M., Uddin, M.K., Samedani, B., Puteh,A. and Man, A. (2013). Integration of agronomic practices with herbicides for sustainable weed management in aerobic rice. The Scientific World J., 2013 article ID 916408. http:// dx.doi.org/10.1155/2013/916408

Araya, A. and Stroosnijder, L. (2010). Effects of tied ridges and mulch on barley (Hordeum vulgare) rainwater use efficiency and production in Northern Ethiopia. Agr. Water Manage., 97: 841-847.

Bertholdsson, N.O. and Brantestam K.A. (2009). A century of Nordic barley breeding - effects on early vigour root and shoot growth, straw length, harvest index and grain weight. Eur. J. Agron. 30: 266-274.

Borghi,E., Costa,N.V., Crusciol,C.A.C. and Mateus,G.P. (2008). Influence of the spatial distribution of maize and Brachiaria brizantha intercropping on the weed population under no-tillage. Planta Daninha., 26 (3): 559-568.

Brar, A.S. and Walia, U.S. (2010). Rice residue position and load with weed control treatment-interferance with growth and development of Phalaris minor and wheat. Indian J. Weed Sci., 42: 163-167.

Chaudhary, S.U., Hussain, M., Ali,M. A. and Iqbal, J. (2008). Effect of weed competition period on yield and yield components of wheat. J. Agric. Res. 46(1): 47-53.

Chhokar, R.S., Sharma, R.K., Chauhan, D.S. and Mongia, A.D. (2006). Evaluation of herbicides against Phalaris minor in wheat in northwestern plains. Weed Res., 46: $40-49$.

Chung, I.M., Ahn, J.K. and Yun, S.J. (2001). Identification of allelopathic compounds from rice (Oryza sativa L.) straw and their biological activity. Can. J. Plant Sci., 81 (4): 815-819.

El-Shahawy, T.A., El-Rokiek, K.G., F.A. Sharara and Khalaf, K.A. (2006). New approach to use rice straw waste for weed control. I. Effect of rice straw extract on controlling broad-narrow leave weeds in cucumber (Cucumis sativa L.). Int. J. Agr. Biol., 8: 262-268.

Gomez, K.A. and Gomez, A.A. (1984). Statistical procedures in agricultural research, $2^{\text {nd }}$ Edition. John Wiley \& Sons, U.K.

Joshi, A.K., Chand, R., Arun, B., Singh, R.P. and Ortiz, R. (2007). Breeding crops for reduced-tillage management 
in the intensive, rice-wheat systems of South Asia. Euphytica 153:135-151.

Kasirajan, S. and Ngouajio, M. (2012) Polyethylene and biodegradable mulches for agricultural applications: a review. Agron. Sustain. Dev., 32:501-529.

Kato-Noguchi, H. (2000). Allelopathy in maize II: Allelopathic potential of a new benzoxazolinone, 5-chloro-6methoxy-2-benzoxazolinone and its analogues. Plant Prod. Sci., 3 (1):47-50.

Khan, M.H.N. (2002). Wheat crop yield loss assessment due to weeds. Sarhad J. Agric., 18 (4): 449-453.

Kumar, S., Agarwal, A. and Kumar, P. (2008). Effect of culture methods on weed population and grain yield of wheat (Triticum aestivum L.). Vegetos, 21 (1): 61-63.

Lemerle, D., Verbeek, B., Cousens, R.D. and Coombes, N.E. (1996). The potential for selecting wheat varieties strongly competitive against weeds. Weed Res., 36: 505-513.

Sharma, I., Singh, G., Tyagi, B.S. and Sharma, R.K. (2013). Wheat improvement in India-Achievement and future challenges. In: Souvenir of All India wheat and barley research workers' meet held on Sep 1-4, 2013. pp 8-20.

Sharma, R. (2009). Integrated weed management technologies in wheat (2009). In: Sharma, R.K., Aggarwal,S., Singh, A.M., Sharma, J.B. (eds), Consolidating the productivity grain in wheat-An Outlook, Indian Agricultural Research Institute, New Delhi. pp 52-56.

Sharma. R, Agarwal, A. and Kumar, S. (2008). Effect of micronutrients on protein content and productivity of wheat (Triticum aestivum L.). Vegetos, 21(1): 51-53.

Singh, M., Singh, M.K., Rakshit, A., Prasad, S.K. and Kumar, K. (2014). Herbicides, nitrogen-scheduling and -rates effects on economics of wheat (Triticum aestivum L.). Econ. Affairs, 59 (4): 663-667.
Singh, M., Singh, M.K., Singh, S.P. and Sahu, R. (2015). Herbicide and nitrogen application effects on weeds and yield of wheat. Indian J. Weed Sci., 47 (2): 125-130.

Singh, M.K. and Saini, S.S. (2008). Planting date, mulch, and herbicide rate effects on the growth, yield, and physicochemical properties of menthol mint (Mentha arvensis L.). Weed Technol. 22: 691-698.

Singh,S. (2007). Role of management practices on control of isoproturon-resistant littleseed canary grass (Phalaris minor) in India. Weed Technol., 21: 339-346.

Singh, S. and Chhokar, R.S. (2012). Integrated weed management strategies for sustainable wheat production. In: Singh, S.S., Hanchinal, R.R., Singh, G.N., Sharma, R.K., Tyagi, B.S., Saharan, M.S. and Sharma, I. (eds.) Wheat- Productivity enhancement under changing climate. Narosa Publishing House, New Delhi, pp 197 205.

Singh, V., Singh, H. and Raghubanshi, A.S. (2013). Competitive interactions of wheat with Phalaris minor or Rumex dentatus: A replacement series study. Int. J. Pest Manage., 59 (4): 245-258.

Swaminathan, M.S. (2013). Genesis and growth of the yield revolution in wheat in India: Lesson for shaping our agricultural destiny. In: Souvenir of All India wheat and barley research workers' meet held on Sep.1-4. pp 1-7.

Unkovich, M., Baldock, J. and Forbes, M. (2010). Variability in harvest index of grain crops and potential significance for carbon accounting: Examples from Australian agriculture. Adv. Agron., 105: 173-219.

Vincent, D. and Quirke, D. (2002). Controlling Phalaris minor in the Indian rice-wheat belt, ACIAR Impact Assessment Series No. 18. pp10. 